\title{
Constraint Analysis of Traditional Methods of Extension Communication in Adoption of Scientific Dairy Practices
}

\author{
Jaspal Singh $^{1}$, Pranav Kumar ${ }^{2 *}$ and Amandeep Singh ${ }^{3}$ \\ ${ }^{1}$ Indian Army Remount \& Veterinary Corps, ${ }^{2}$ Division of Veterinary \& Animal Husbandry \\ Extension Education, Faculty of Veterinary Sciences \& Animal Husbandry, Sher-E-Kashmir \\ University of Agricultural Sciences \& Technology of Jammu, R.S. Pura, \\ Jammu, Jammu \& Kashmir (181102), India \\ ${ }^{3}$ Division of Extension Education, ICAR-Indian Veterinary Research Institute, Izatnagar, \\ Bareilly, Uttar Pradesh (243122), India \\ *Corresponding author
}

\begin{tabular}{l} 
K e y w o r d s \\
$\begin{array}{l}\text { Communication, } \\
\text { Constraint, Farmers, } \\
\text { Scientists, Traditional } \\
\text { extension }\end{array}$ \\
\hline Article Info \\
$\begin{array}{l}\text { Accepted: } \\
\text { 26 July } 2018 \\
\text { Available Online: } \\
10 \text { August } 2018\end{array}$ \\
\hline
\end{tabular}

\section{Keywords}

Communication,

Constraint, Farmers,

Scientists, Traditional extension

\section{Article Info}

Accepted:

26 July 2018

10 August 2018

\section{A B S T R A C T}

Traditional extension methods of communication system have numerous limitations in adoption of technologies. It involves a lot of time and efforts to deliver the message. The quality of extension messages gets heavily distorted and eroded when it ultimately reaches the end users. Most of technical staff within the state departments of animal husbandry lacks the capacity to effectively communicate with both the research system and the stakeholder group. Keeping all these points in mind a study was conducted to identify and document the constraints in adoption of scientific dairy practices by following the traditional methods of extension communication as perceived by scientists and farmers. The constraints were studied at field, institutional and technical levels for scientists and field, institutional and individual levels for farmers. On analysis it was found that 70 per cent of the scientists perceived lack of motivated extension workers at grass root level as major field level constraint followed by 45 per cent who stated lack of sufficient extension aids, tools and techniques in the department of animal husbandry and other line departments as major institutional constraint. Among technical constraints, 50 per cent of the scientists stated that traditional methods of extension are not much interactive compared to other media. Among farmers, 69.16 per cent, 76.66 per cent and 85 per cent perceived that outdated information is provided through the traditional methods is major field level constraint, agriculture/livestock information on radio and television is mostly broadcasted at odd hours as major institutional constraint and need based information is not available as major individual constraint respectively. 


\section{Introduction}

Livestock extension education seeks to impart the necessary skills to the farmers for undertaking improved animal husbandry operations, to make available timely information and improved practices in an easily understandable form suited to their level of literacy and awareness and to create in them a favorable attitude for innovation and change (Benor, 1984). National Sample Survey Organization (NSSO, 2005) survey reported that 60 percent of the farmers do not access any source of information for advanced agricultural technologies. As a result, there is a wide adoption gap among farming community to achieve the vertical increase in production through optimum resource utilization. With the advent of information and communication technologies (ICTs), the role of traditional extension methods are decreasing day by day. Before one can appreciate the importance of ICTs in livestock extension, it may be helpful to take a look at some of the limitations of traditional livestock extension techniques and processes. The traditional extension system costs a lot of money to produce and print materials. It involves a lot of time and efforts to deliver the message. The quality of extension messages gets heavily distorted and eroded when it ultimately reaches the end users. Most of the technical staff within the state departments of animal husbandry (SDAHs) lacks the capacity to effectively communicate with both the research system and the stakeholder group.

In India, of the required 1.3 million to 1.5 million extension personnel, there are only about 0.1 million on the job (Working Group on Agricultural Extension 2007). It is observed that most of the staffs associated with extension work are on adhoc or contractual basis, or given additional charges. According to Kumar et al., (2012), the centralized and top - down approach, the political bureaucratic patronage and low level of real involvement /participation of farming community have become the pit-falls of extension services. The Extension Service is mostly through interpersonal contact method which is costly, time consuming and personnel-intensive. This service is still target oriented and production focused rather than farmer income oriented. The system consists of less trained professionals with crop oriented rather than farm enterprise mix concept. There is low use or no- use of modern communication tools and techniques. Our crop production has a major priority for most extension services but not livestock production although the demand for livestock products is growing more rapidly than the demand for crops (Mathewman and Mortan 1995). On the other hand potential advantages of ICTs are that it save money, time and effort. It cut steps involved in the dissemination of information among the farmers. The information is rich and interactive which creates a curiosity among farmers to know more about various innovations in agriculture and allied fields (Kumar et al., 2012).

Further, Asian countries experience extension staff shortages in remote, marginal and underdeveloped areas. Many extension officers are forced have to undertake nonextension activities and tasks, making advisory work suffer and in cases ineffective (Shalaby et al., 2011). Due to this, the extension staff regresses from its activities which ultimately lead to suffering of the farmers. According to a report by Anandajayasekeram et al., (2008), extension staff is not well equipped with appropriate skills for their efficient functioning. Therefore it is important that skills of extension agents must be improved, their working knowledge be updated, and they should have innovative ideas in order to develop agriculture. Inadequate finances and funding, lack of 
qualified and trained extension staff; poor weak and deteriorated infrastructure; lack or weak coordination mechanisms and functional linkages with the other institutions in both the public and private sectors, absence of quality control and impact assessment mechanisms; unclear extension mandates and lack of job descriptions related to staff further aggravate the grievances pertaining to traditional extension communication (FAO, 2005; APO, 2006, Shalaby, 2011).

\section{Materials and Methods}

The study was conducted in Jammu district of Jammu and Kashmir State. Jammu district of Jammu and Kashmir state was selected because of the presence of good number of dairy animals and also due to the presence of socially and educationally improved dairy farmers in the district. Jammu district having ten blocks was divided into cluster of five areas. From each cluster one block was selected at random, making a total of five blocks for the study. From the selected blocks, two villages per block were selected purposively where good number of dairy farmers were present comprising of small farmers (2-6 dairy animals), medium farmers (6-15 dairy animals) and large farmers (>15 dairy animals). From all the selected blocks, a total of one hundred and twenty dairy farmers were selected through proportionate random sampling method (twelve dairy farmers from each selected village). A total of twenty scientists from Faculty of Veterinary Sciences and Animal Husbandry, R.S. Pura were selected at random for the study. The present study was conducted to identify and document the constraints in adoption of scientific dairy practices by following the traditional methods of extension communication as perceived by scientists and farmers.

An appropriate semi structured interview schedule was prepared by consulting experts and concerned literature. The interview schedule was prepared for dairy farmers and for scientists. Thus constructed interview schedule was pre-tested among the nonsample respondents of the study area for testing its suitability and its appropriateness in getting responses.

With the necessary modifications, the final interview schedule was prepared for dairy farmers. Personal interview method was followed for data collection in which interview schedules were prepared both for the dairy farmers and scientists in dairy sector. The data was analyzed using Statistical Package for Social Sciences (SPSS) statistical tool.

\section{Results and Discussion}

The constraints perceived by the scientists and farmers are studied at different levels. For scientists, the constraints were studied at field level, institutional level and technical constraints. For farmers, the constraints were studied at field level, institutional level and individual constraints. The constraints are discussed in the following subheads.

\section{Constraints in adoption of scientific dairy practices by following the traditional methods of extension communication as perceived by scientists}

Traditional methods of extension education played a very important role in the past for the dissemination of the information among the farmers through various techniques.

These techniques were successful in the past, but still they are not up to the mark. For the present study constraints experienced by dairy farmers as perceived by scientists were collected, analyzed and on the basis of the frequency of the response, there ranking is done as presented in Table 1. 


\section{Field level constraints}

On perusal of Table 1 and Figure 1(a), it is clear that under field level constraints that majority $(70 \%)$ of the respondents believe that 'lack of motivated extension workers at the grass root level' is the major constraint followed by "poor public relation of the extension workers' (45\%) in adoption of scientific practices by dairy farmers. While 30 per cent respondents stated that due to 'farmer illiteracy', the traditional methods of extension are ineffective. The results obtained are in line with Ali et al., (1994) and Anderson and Feder 2004 and Shalaby et al., (2011). They reported that the ineffectiveness of the extension workers is due to their engagement in works other than extension. Further, factors like lack of transport, heterogeneous nature of these areas and under developed infrastructure prevent the extension workers to perform their duties (Antholt, 1994). Omar et al., (2012) also summarized their study on the similar findings.

\section{Institutional constraints}

According to table 1 and Figure 1(b), under institutional constraints it is evident that most (45\%) believe 'lack of sufficient extension aids, tools and techniques in the department of animal husbandry and other line departments' as constraint and it is followed by 40 per cent for 'traditional methods of extension are time consuming affairs'.

On the other hand only 25 per cent believe 'lack of fund from state animal husbandry departments in executing extension works' as important constraint. The study is in agreement with the findings of APO (2006) which states that the availability of insufficient finances and at occasions their interrupted availability constraint the extension activities in most of the Asian countries. Baig et al., (1995) also reported the similar findings and stated that poor roads, unsatisfactory means of transport and lack of communication facilities make the job of the extension worker difficult and harder, if not impossible, preventing them reaching their clienteles. Omar et al., (2012) also reported the poor public relations of the extension workers which serve as a limiting factor to development.

\section{Technical constraints}

Table 1 and Figure 1(c) under technical constraints reveals that majority $(50 \%)$ respondents think 'traditional methods of extension are not much interactive', followed by $(45 \%)$ believe 'editing of extension literature (books, folders, leaflets etc.) from time to time is a serious problem' and only $(25 \%)$ think 'printing errors at the time of extension literature preparation' as constraint in adoption of scientific dairy practices.

The findings of the study are in agreement with those of Azeez and Jimo (2003). With the usage of electronic gadgets, the use of paper for drastically reduced and people find more engaged in the activity which involve higher number of their senses which forms the overall interactivity of the media. Omar et al., (2012) stated that the poor funds with extension agencies also put a barrier in the extension activities to be carried out for development.

\section{Constraints in adoption of scientific dairy practices by following the traditional methods of extension communication as perceived by dairy farmers}

An attempt was made to find out the problems/constraints faced by dairy farmers in adoption of scientific dairy practices by following the traditional methods of extension communication. The problems given by the respondents were ranked based on frequency and percentage and presented in the Table 2. 
Table.1 Constraints in adoption of scientific dairy practices by following the traditional methods of extension communication as perceived by scientists

\begin{tabular}{|c|c|c|c|c|}
\hline $\begin{array}{l}\text { S. } \\
\text { No }\end{array}$ & Particulars & Frequency & Percent & Rank \\
\hline & Field level constraints & & & \\
\hline 1 & $\begin{array}{l}\text { Most of the farmers are illiterate, so they are unable } \\
\text { to understand the extension literature }\end{array}$ & 6 & 30.00 & V \\
\hline 2 & $\begin{array}{l}\text { Lack of access roads for easy community visit of } \\
\text { extension workers }\end{array}$ & 8 & 40.00 & III \\
\hline 3 & $\begin{array}{l}\text { Lack of motivated extension workers at grass root } \\
\text { level }\end{array}$ & 14 & 70.00 & I \\
\hline 4 & Poor public relation of extension workers & 9 & 45.00 & II \\
\hline \multirow[t]{2}{*}{5} & $\begin{array}{l}\text { Lack of simplicity of the content in understanding the } \\
\text { information }\end{array}$ & 7 & 35.00 & IV \\
\hline & Institutional constraints & Frequency & Percent & Rank \\
\hline 1 & $\begin{array}{l}\text { Traditional methods of extension work/technology } \\
\text { transfer are costly in nature }\end{array}$ & 6 & 30.00 & IV \\
\hline 2 & $\begin{array}{l}\text { Traditional methods of extension are time consuming } \\
\text { affairs }\end{array}$ & 8 & 40.00 & II \\
\hline 3 & $\begin{array}{l}\text { Lack of sufficient extension aids, tools and } \\
\text { techniques in the department of animal } \\
\text { husbandry and other line departments }\end{array}$ & 9 & 45.00 & I \\
\hline 4 & $\begin{array}{l}\text { Lack of money to purchase newsletters, news } \\
\text { bulletins, farm journals, krishipatrika on agricultural } \\
\text { information }\end{array}$ & 7 & 35.00 & III \\
\hline \multirow[t]{2}{*}{5} & $\begin{array}{l}\text { Lack of fund from state animal husbandry } \\
\text { departments in executing extension works }\end{array}$ & 5 & 25.00 & V \\
\hline & Technical constraints & Frequency & Percent & Rank \\
\hline 1 & $\begin{array}{l}\text { Editing of extension literature (books, folders, } \\
\text { leaflets etc.) from time to time is a serious problem }\end{array}$ & 9 & 45.00 & II \\
\hline 2 & $\begin{array}{l}\text { It is difficult to update the extension literature at the } \\
\text { time of urgent need like (floods, draught, cyclones } \\
\text { etc.) in short period of time }\end{array}$ & 8 & 40.00 & III \\
\hline 3 & $\begin{array}{l}\text { Traditional methods of extension are not much } \\
\text { interactive }\end{array}$ & 10 & 50.00 & I \\
\hline 4 & $\begin{array}{l}\text { Lack of relevance of the content (reliability of } \\
\text { technical knowhow) }\end{array}$ & 6 & 30.00 & IV \\
\hline 5 & $\begin{array}{l}\text { Printing errors at the time of extension literature } \\
\text { preparation }\end{array}$ & 5 & 25.00 & V \\
\hline
\end{tabular}


Table.2 Constraints in adoption of scientific dairy practices by following the traditional methods of extension communication as perceived by dairy farmers

\begin{tabular}{|c|c|c|c|c|}
\hline S. No. & Field level constraints & Frequency & Percent & Rank \\
\hline 1 & Doorstep dissemination of information is not done & 65 & 54.16 & III \\
\hline 2 & $\begin{array}{l}\text { Outdated information is provided through the traditional } \\
\text { methods }\end{array}$ & 83 & 69.16 & I \\
\hline 3 & $\begin{array}{l}\text { Traditional methods of extension work/technology transfer are } \\
\text { costly in nature }\end{array}$ & 34 & 28.33 & $\mathrm{~V}$ \\
\hline 4 & Lack of extension contact during adverse weather conditions & 77 & 64.16 & II \\
\hline \multirow[t]{2}{*}{5} & Lack of simplicity of the content in understanding the information & 54 & 45.00 & IV \\
\hline & Institutional constraints & Frequency & Percent & Rank \\
\hline 1 & Lack of access roads for easy community visit of extension workers & 16 & 13.33 & V \\
\hline 2 & $\begin{array}{l}\text { Agriculture/livestock information on radio and television is } \\
\text { mostly broadcasted at odd hours. }\end{array}$ & 92 & 76.66 & I \\
\hline 3 & Lack of rural electrification/frequent power cuts & 86 & 71.66 & II \\
\hline 4 & Lack of proper marketing places & 27 & 22.50 & IV \\
\hline \multirow[t]{2}{*}{5} & $\begin{array}{l}\text { Lack of fund from state animal husbandry departments in executing } \\
\text { extension works }\end{array}$ & 55 & 45.83 & III \\
\hline & Individual constraints & Frequency & Percent & Rank \\
\hline 1 & $\begin{array}{l}\text { Lack of money to purchase newsletters, news bulletins, farm } \\
\text { journals, krishipatrika on agricultural information }\end{array}$ & 55 & 45.83 & IV \\
\hline 2 & Traditional methods of extension are time consuming affairs & 68 & 56.66 & III \\
\hline 3 & Need based information not available & 102 & 85.00 & I \\
\hline 4 & Poor public relation of extension workers & 87 & 72.50 & II \\
\hline 5 & Non availability of timely information to the farmers & 29 & 24.16 & V \\
\hline
\end{tabular}

Fig.1 (a) Field level constraints

\section{Field level constraints}

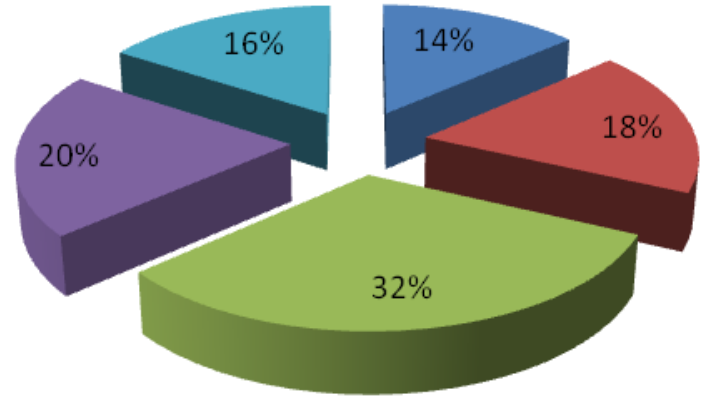

most of the farmers are illiterate

- lack of access roads

- lack of motivated extension workers

poor public relation of extension workers

lack of simplicity of the content 
Fig.1 (b) Institutional constraints

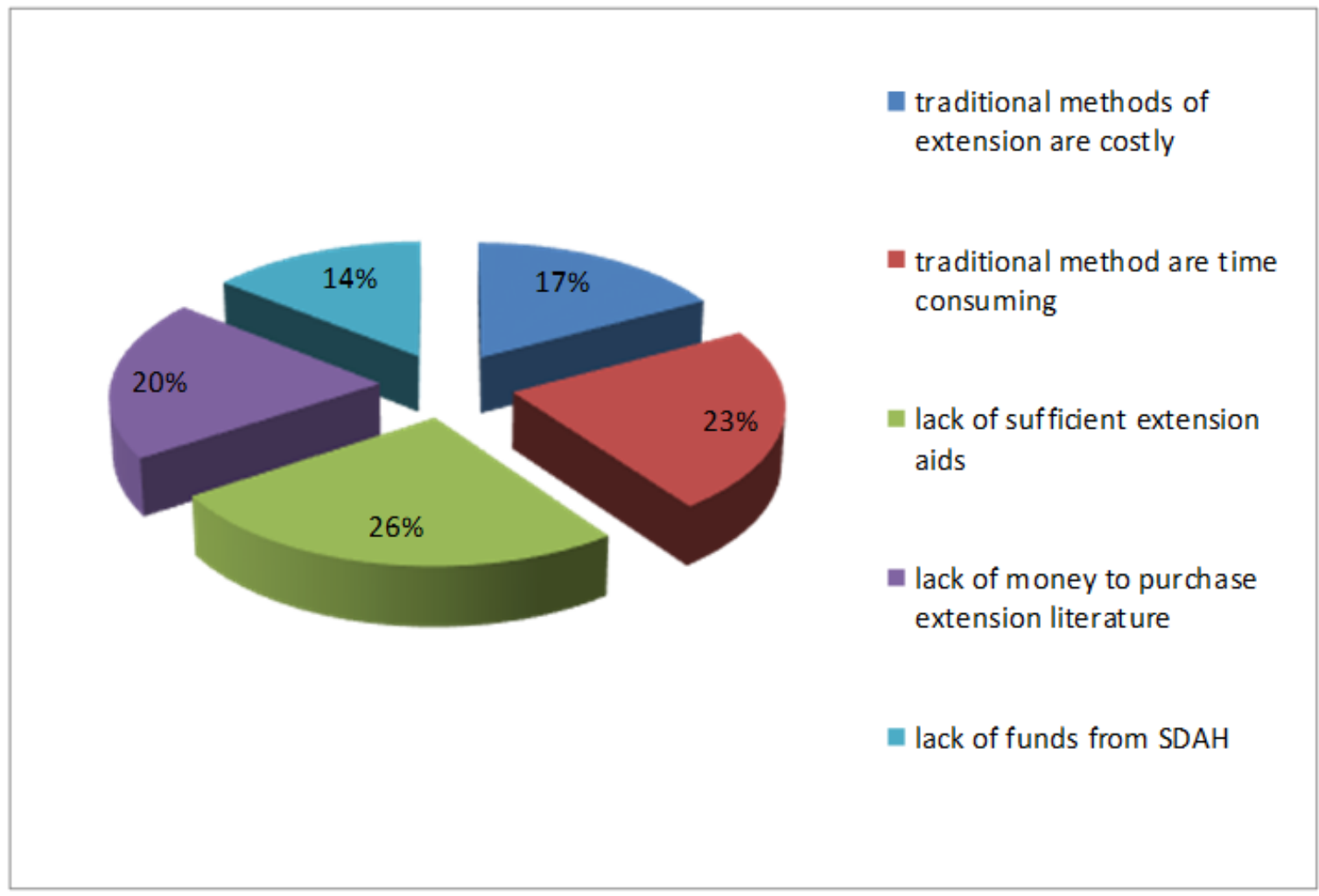

Fig.1 (c) Technical constraints

\section{Technical constraints}

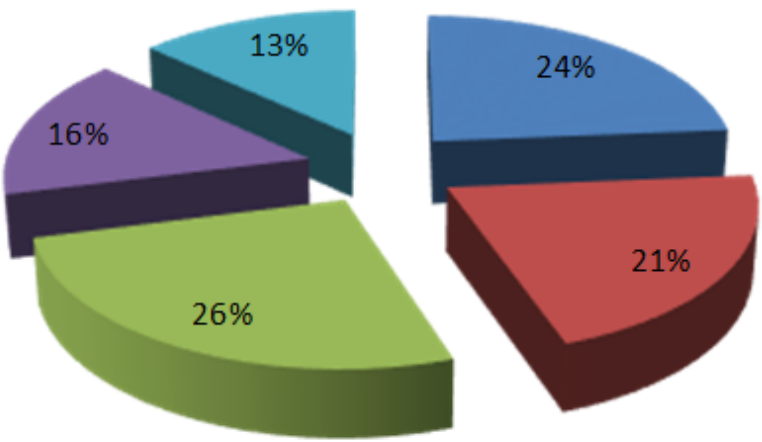

= editing of extension lite rature is a serious problem

afficult to update extension literature

Iraditional method of extension not much interactive

- lack of relevance of content

mprinting errors at the time of literature preparation 
Fig.2 (a) Field level constraints

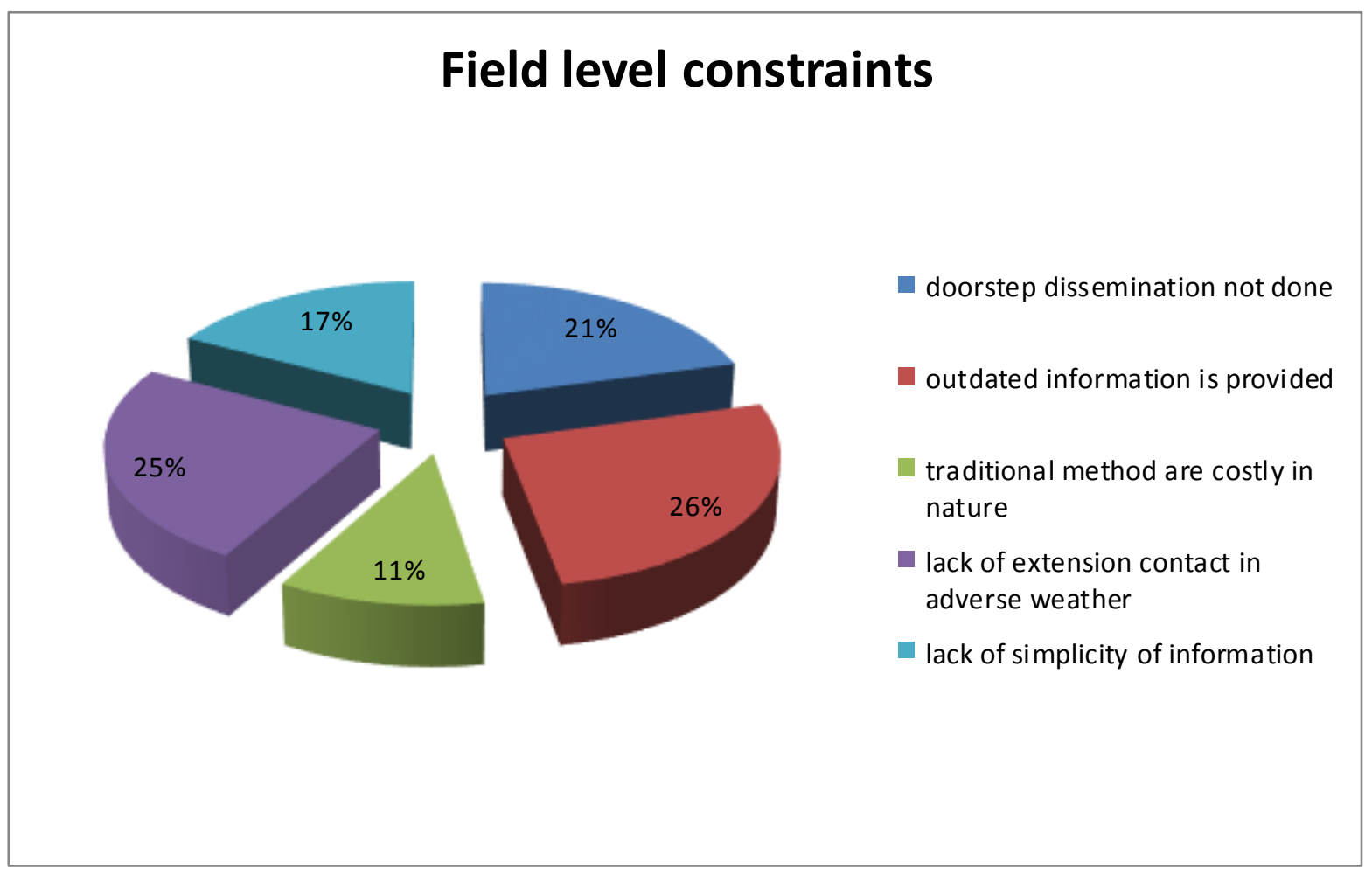

Fig.2 (b) Institutional constraints

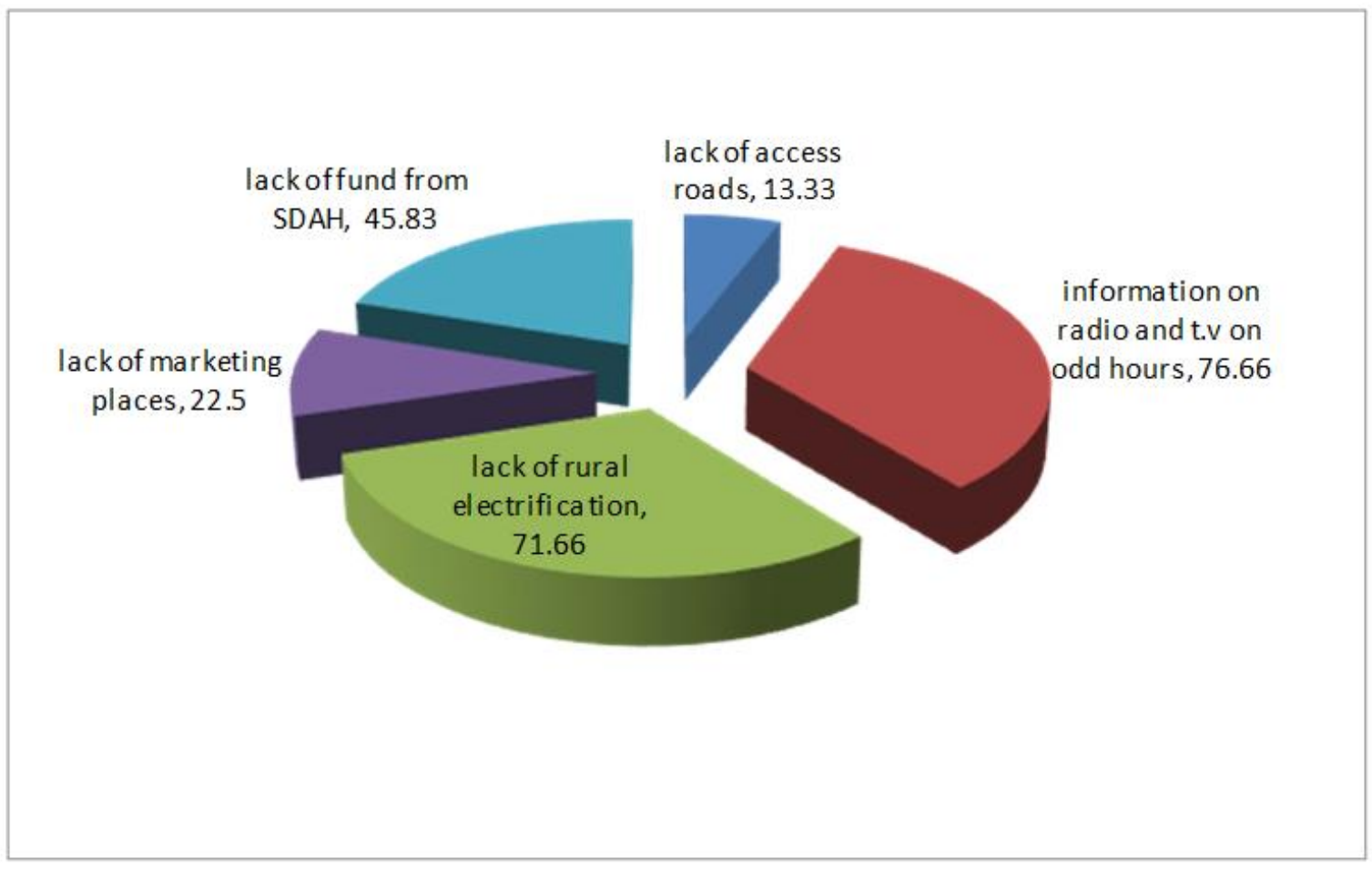


Fig.2 (c) Individual constraints

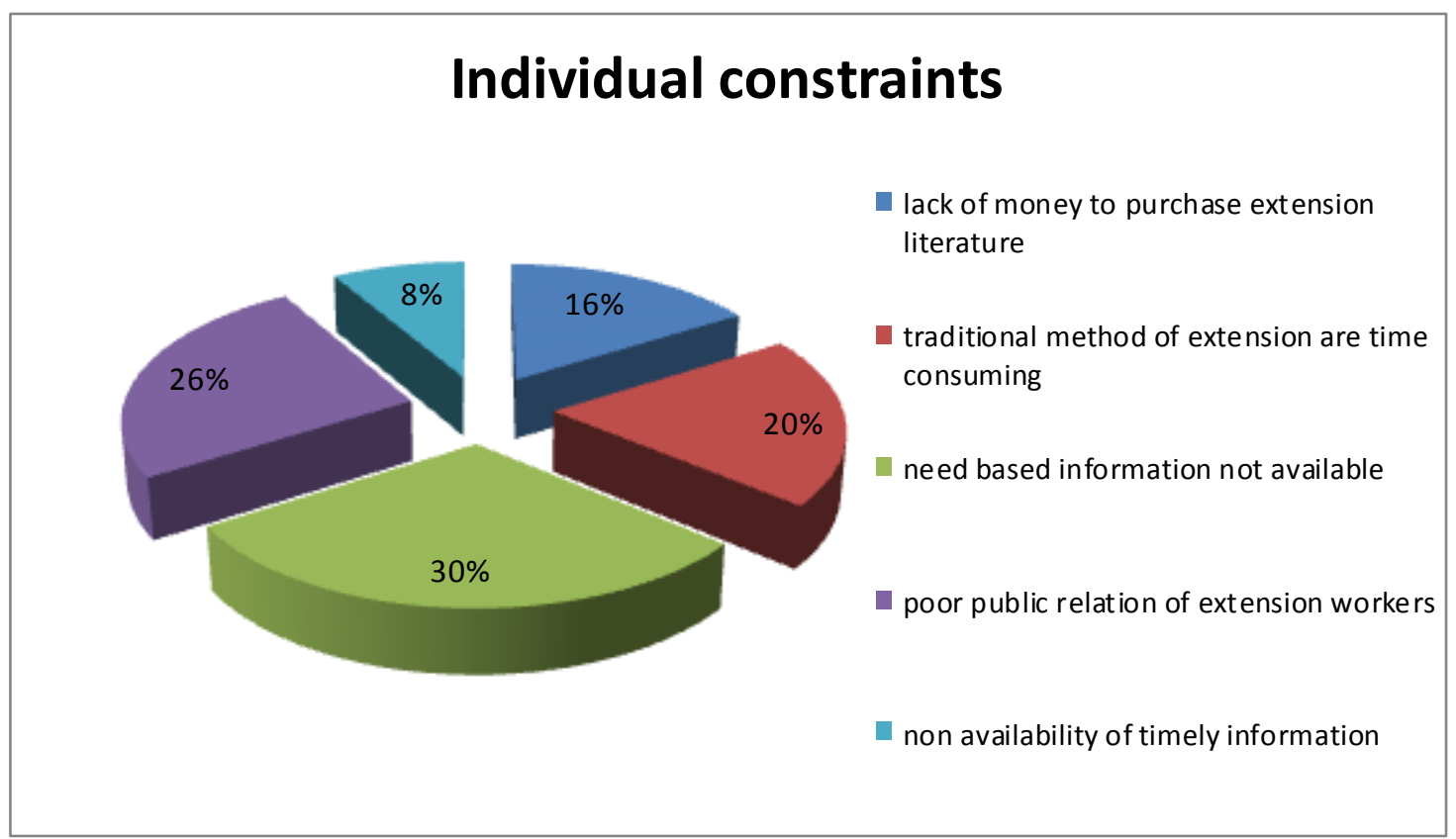

\section{Field level constraints}

On perusal of Table 2 and Figure 2(a), it is clear that under field level constraints majority $(69.16 \%)$ of the respondents believed that 'outdated information is provided through the traditional methods' is the major constraint followed by $(64.16 \%)$ of respondents thought 'lack of extension contact during adverse weather conditions' as constraints in adoption of scientific practices by dairy farmers. Whereas traditional methods of extension work/technology transfer are costly in nature was perceived by only $28.33 \%$ farmers.

The findings of the study are in line with Cho and Boland (2003) and Antholt (1994) who emphasizes on in-service training as of paramount importance to make extension professionals productive and effective and keeping them up to date with the literature and other media of extension delivery system. Eberle and Shroyer (2000) also portrayed the similar findings on the use of traditional media.

\section{Institutional constraints}

According to Table 2 and Figure 2 (b), for institutional constraints it is evident that fair majority (76.66\%) believe agriculture/livestock information on radio and television is mostly broadcasted at odd hours' as most important constraint and it is closely followed by 71.66 per cent for lack of rural electrification/frequent power cuts. On the other hand only 13.33 per cent believe 'lack of access roads for easy community visit of extension workers' as important constraint. The findings of the study are in line with that of Baig et al., (1995) and Omar et al., (2012).

\section{Individual constraints}

Data in Table 2 and Figure 2(c) under individual constraints reveals that greater majority $(85.00 \%)$ respondents thought 'need based information not available' as the most important constraint, followed by $(72.50 \%)$ believe 'traditional methods of extension are time consuming affairs' and only (5.00\%) of the respondents thought 'poor public relation 
of extension workers' as constraint in adoption of scientific dairy practices. The findings of the study are in agreement with those reported by Omar et al., (2012). Similar findings on the information needs from electronic media were reported by Bachhav (2012) and Galadima (2014).

Since earlier times, traditional extension approaches has proved its metal for development of agriculture and allied sectors. With time, the extent and arena of extension delivery has increased, therefore, it is important to address and accommodate the emerging trends and challenges faced by the traditional extension today. For example, information and communication technology (ICT) when combined with other approaches and methods has the great potential to compliment the extension initiatives. It is possible to make use of ICT for enhancing linkages and coordination among different stakeholders, for the betterment of the farmers and for overall development. The study is concluded with a view that developing need based expert systems, web kiosks, web portals, mobile apps and other internet based extension delivery systems along with digital literacy of the farmers can serve the ever increasing needs of livestock farmers. These ICT initiatives can substantially reduce the felt constraints and give a better impetus to livestock development.

\section{References}

Ali, T., Khan.S. A., Malik. N. H., Ahmad, M. and Saleem, I. (1994). Investigation into some common factors which affect agricultural Research and Extension work in developing countries. Pakistan J. Agri. Sci., 31(3): 245-249.

Anandajayasekeram, P., Puskur. R., Sindu, W. and Hoekstra, D. (2008). Concepts and Practices in Agricultural Extension in Developing Countries: A source book. IFPRI (International Food Policy Research Institute), Washington DC, USA, and ILRI (International Livestock Research Institute), Nairobi, Kenya.

Anderson, J. R., and Feder, G. (2004). Agricultural Extension: Good intentions and Hard Realities. The International Bank for Reconstruction and Development. The World Bank. The World Bank Research Observer. 19(1):41-60

Antholt, C. H. (1994). Getting ready for twenty-first century. Technical change and institutional modernization in agriculture. World Bank Technical Paper 217. Asia technical department series. World Bank, Washington DC. pp. 1-46.

APO (2006).Enhancement of Extension Systems in Agriculture. In. Report of the APO Seminar on Enhancement of Extension Systems in Agriculture, held in Pakistan, 15-20 December, 2003. Organized by the Asian Productivity Organization, Japan.

Azeez, I.O. and Jimo, S.O. (2003). Traditional medial use in Forest conservation support communication (FCSC) among local residents in protected areas in South Western, Nigeria. Journal of Environmental Extension, 4: 19-30.

Bachhav, N.B. (2012). Information Needs of the Rural Farmers: A Study from Maharashtra, India: A Survey. University of Nebraska-Lincoln. Library Philosophy and Practice (ejournal). 866.

Baig, M. B. and Ehrenreich, J.H., Straquadine, G. S., Sleight, W.S. and Derry, J.O. (1995). Agricultural extension and transfer of technology in Asian countries. p. 118-123. In. J.H. Ehrenreich (Eds.) Fourth North American Agro forestry Conf. 23-28 July, Boise, Idaho, USA. 
Benor, D. (1984). Training and Visit system. A World Bank publication. The World Bank Washington DC, 138.

Cho, K. M. and Boland, H. (2003). Toward a sustainable development in Agriculture: An analysis of training needs for extension agents in Myanmar. Deutscher Trpentag, Oct 8-10, 2003, Gottingen. International Research on Food Security, Natural Resource Management and Rural Development. Technological and Institutional Innovations for Sustainable Rural Development.

Eberle, W.M. and Shroyer, J.P. (2000). Are Traditional Extension Methodologies Extinct or Just Endangered? J. Nat. Resour. Life Sci. Educ., Vol. 29; 135-40

FAO (2005).Options of reform for agricultural extension in the Near East. In. Proceedings of Regional Workshop on Options of Reform for Agricultural Extension in the Near East, Amman, Jordan. October 2-4, 2004. Food and Agriculture Organization of the United Nations Regional Office for the Near East Cairo, Egypt.

Galadima, M. (2014).Constraints on Farmers Access to Agricultural Information Delivery: A Survey of Rural Farmers in Yobe state, Nigeria. IOSR Journal of Agriculture and Veterinary Science (IOSR-JAVS). 7(9) Ver. II; 18-22

Kumar, U., Kumar, A. and Thakur, P.K. (2012).Status and Constraints of Extension Services. Status of Agricltural Development in Eastern
India. Eds: B.P. Bhatt, A.K. Sikka, Joydeep Mukherjee, Adlul Islam, A. Dey (2012). ICAR Research Complex for Eastern Region, Patna. pp. 479-492

Mathewman and Mortan (1995). New challenges for livestock extension: Information needs, institutions and opportunities. Natural Resources Institute, Chatham, United Kingdom.

NSSO (National Sample Survey Organization, 2005). Situation assessment survey of farmers: Access to modern technology for farming, 59th round (January-December 2003). Report No. 499(59/33/2). Ministry of Statistics and Programme Implementation, New Delhi.

Omar, A.E.J., Abu Bakar, A.H., Jais, H.M. and Shalloof, F.M. (2012).The impact of major constraints on agricultural extension ineastern Libya. Journal of Agricultural Technology. Vol. 8(4): 1171-1183

Shalaby, M. Y., Al-Zahrani, K. H., Baig, M. B., Straquadine, G. S. and Aldosari, F. (2011). Threats and Challenges to Sustainable Agriculture and Rural Development in Egypt: Implications for Agricultural Extension. Journal of Animal and Plant Sciences. 21(3): 581588.

Working Group on Agricultural Extension (2007). Recommendations of working group on agricultural extension for formulation of eleventh five-year plan (2007-12). New Delhi: Planning Commission.

\section{How to cite this article:}

Jaspal Singh, Pranav Kumar and Amandeep Singh. 2018. Constraint Analysis of Traditional Methods of Extension Communication in Adoption of Scientific Dairy Practices. Int.J.Curr.Microbiol.App.Sci. 7(08): 4522-4532. doi: https://doi.org/10.20546/ijcmas.2018.708.479 